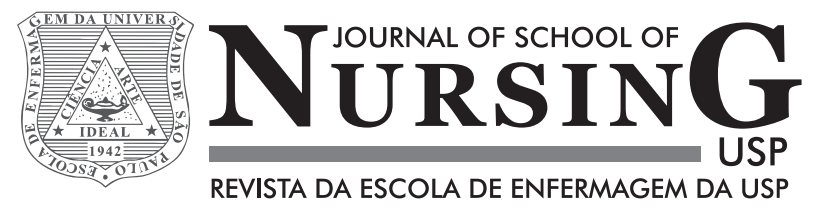

\title{
Map of homicides by firearms: profile of the victims and the assaults
}

\author{
Mapa dos homicídios por arma de fogo: perfil das vítimas e das agressões \\ Mapa de los homicidios por arma de fuego: perfil de las víctimas y las agresiones
}

Ruth França Cizino da Trindade ${ }^{1}$, Flávia Azevedo de Mattos Moura Costa², Patrícia de Paula Alves Costa da Silva ${ }^{1}$, Gustavo Bussi Caminiti ${ }^{3}$, Claudia Benedita dos Santos ${ }^{4}$

\footnotetext{
${ }^{1}$ Universidade Federal de Alagoas, Maceió, AL, Brazil.

${ }^{2}$ Universidade Estadual de Santa Cruz, Ilhéus, BA, Brazil.

${ }^{3}$ Universidade de Ribeirão Preto, Ribeirão Preto, SP, Brazil.

${ }^{4}$ Universidade de São Paulo, Escola de Enfermagem de Ribeirão Preto, Ribeirão Preto, SP, Brazil.
}

\begin{abstract}
Objective: Describing the profile of victims and assaults by gunshot, where the outcome was death. Method: An ecological study conducted in the city of Maceió/AL, in 2012. Data were collected from the death statements. The variables studied were: the death circumstances, gender, age, marital status, place, date, time, month and proportion according to the occurring neighborhood. Results: The homicide mortality rate was 65.2 per 100,000 inhabitants, with 130.6 per 100,000 men and 7.8 per 100,000 women. Of the total number of homicides, $93.6 \%$ of the victims were men. The age group between 15 and 29 years of age was the most affected, with $68.8 \%$. In $97.6 \%$ of cases the death occurred at the site of aggression, $74.1 \%$ in the streets. In relation to the date, $54.2 \%$ of cases occurred between Friday and Sunday. $59.7 \%$ of the homicides were concentrated in seven neighborhoods. Conclusion: The map of violence presented shows heterogeneous areas for the occurrence of assaults with firearms, characterizing the existing urban inequality in violence distribution.
\end{abstract}

\section{DESCRIPTORS}

Violence; Homicide; Mortality Rate; Social Inequity; Ecological Studies.

\section{Corresponding author:}

Ruth França Cizino da Trindade

Universidade Federal de Alagoas, Escola de

Enfermagem e Farmácia - Campus A. C. S.

Simões

Av. Lourival Melo Mota, s/n - Cidade

Universitária

CEP 57072-900 - Maceió, AL, Brazil.

ruth.trindade@esenfar.ufal.br
Received: 06/12/2014

Approved: 05/23/2015 


\section{INTRODUCTION}

Growing violence morbidity and mortality rates in Brazil exposes the population to constant health risks, which makes this issue a priority public health problem ${ }^{(1-2)}$.

Several studies have pointed to the existence of the real growth of violence in Brazil, particularly homicides, since the late $1970 s^{(3)}$. Geographic regions and their respective municipalities, mainly the larger cities, have shown an increase in mortality from external causes since the $1990 \mathrm{~s}^{(3)}$. Among other explanations, this fact may be related to vulnerability and exposure to the occurrence of violence, as well as an inability to react to it. The mortality information is one of the most important in the health area, because death is a unique event and its registration is required.

There is a growing number of studies on violence and, on a smaller scale, the problem of firearms use, possession and distribution in Brazil is also receiving increasing attention ${ }^{(3)}$.

An increase in the use of firearms in deaths from assault has been observed, and gunshot wounds have been identified as being responsible for the increase in deaths from homicide in Brazil. However, in the municipality of São Paulo there has been a reduction in homicides between 2001 and 2008. This decrease occurred across the board, both in urban areas and in the different population groups, with a tendency/strategy to approach and reduce the inequalities in the risk of death ${ }^{(4)}$.

The National Council of Municipalities (Conselho $\mathrm{Na}$ cional dos Municipios - CNM) considers it important to measure the murders committed, not only due to the severity of this type of crime, but also because it is an accurate barometer of violent crime in the context in focus, as well as the frequency of the use of firearms in the act of such crimes ${ }^{(5)}$.

Another problem in deaths from violence is due to the fact that it victimizes the young population range, which causes violent deaths and are the leading cause of death among adolescents and young adults ${ }^{(6-7)}$.

A study of homicides in Itabuna/BA from 2000 to 2012 found that the data on homicide mortality rates in males showed an increase in all age groups, especially between 15 and 29 years of age. The coefficients increased from 1.0 to 6.2 deaths per 1,000 inhabitants, as did the female, where the highest rates were also recorded in this age group, ranging from 0.08 in 2000 to 0.11 in $2012^{(7)}$.

A study with health professionals of the Family Health Strategy found that violence seldom appears as an immediate demand service, but it is substantial as implied demand, requiring the expansion of the professional work objective to recognize it as a problem whose prevention and coping are inherent in the sector, as this is a reality that has an intrinsic relation to the health-disease process, focusing on all acting in health ${ }^{(8)}$ and it affects the victims, as well as the family and the community where they live.

The city of Maceió, capital of Alagoas, is inserted in this context as one of the most violent cities in the country. In 1998, Maceió occupied intermediate positions and currently is proportionally among the most violent among the state capitals of Brazil, with the thirteenth place of deaths from this type of injury in 2005, becoming the capital with the highest rates of homicide in the country $^{(9)}$ since 2008.

Due to the magnitude of the violence problem in Brazil, on June 27,2012 the national plan for public safety was released in Alagoas, called the Program for a More Safe Brazil (Programa Brasil Mais Seguro) ${ }^{(10)}$. This plan intends to focus on three points: improvement in the investigation of violent deaths; increased ostensible and community policing; and gun control. The program was initially implemented in the state of Alagoas. Thus, National Force has been installed in the state since June 2012, working on its security forces to meet these goals ${ }^{(10)}$. The program's performance lies guided in controlling crime, requiring that the state and federal governments to implement public policies aimed at improving the economic conditions that generate social inequalities, such as increasing jobs and reducing poverty, which are closely related to violence.

Considering all these aspects and local specificities comes the need to understand the magnitude of deaths from violence in the city of Maceió, capital of Alagoas, keeping in mind it is a municipality with 953,393 inhabitants, representing $30.12 \%{ }^{(11)}$ of the population of Alagoas in 2012. Given the current existing conditions, knowledge of the reality is an indispensable condition so that we can mobilize and unite governmental and non-governmental efforts for solving them. Moreover, it is a city with an intensity of tourist attractions, but with great social inequalities, which contrast with the desired development in Brazil. The 2014 Human Development Report describes the lack of social cohesion being correlated with conflict and violence, especially in situations of inequality of access to resources or to the benefits of natural wealth, and the inability to cope with social change ${ }^{(12)}$.

As a result, this study aims to identify the magnitude of homicides from gunshots in a northeastern Brazilian capital and to characterize homicide victims of gunshots, as well as assaults by firearm with the outcome of death in 2012 .

\section{METHOD}

This is an ecological study on mortality from assault, specifically deaths from homicide which occurred from gunshots in the city of Maceió, capital of Alagoas state in 2012.

Ecological studies correspond to the aggregate-observational-transverse design, which uses geographical references and enables synthesizing a set of variables and a social reality approach, where the unit of analysis is a population or group of people who usually belong to a defined area ${ }^{(13)}$.

The development of this research was approved by the Research Ethics Committee (Comitê de Ética em Pesquisa CEP) under number 09664212.8.0000.5013. The subjects were all victims of assault by firearm, residents in Maceió and an outcome of death, which occurred in the same municipality. Data collection was carried out by consulting the Death Declaration (DD) in the Epidemiology Sector in the Maceió City Department of Health. 
The variables studied in relation to the victims were gender, marital status and age, and in relation to assault, place, date and proportion according to neighborhood occurrence. Deaths have also been reported according to place of occurrence.

The following epidemiological measures of mortality were used: mortality rate (/100.000 inhabitants) and mortality due to homicides by firearm (/100), for total population, age group and gender.

The variables education and occupation were not considered due to the high number of non-specific DD. Deaths of city residents were selected whose underlying causes have been identified in the twentieth chapter of the International Classification of Diseases (ICD-10), referring to external causes of morbidity and mortality that register deaths from accidents, poisoning, burning, drowning etc. In this chapter, deaths by firearms are grouped into categories: W32 to W34 of deaths from unintentional injuries; X72 to X74 of intentional self-harm or suicide; X93 to X95 intentional homicides or assaults; and Y22 to Y24 of the undetermined intent chapter.

To calculate mortality rates, we used the inter-census projection provided by the DATASUS, based on the population census of the Brazilian Institute of Geography and Statistics (Instituto Brasileiro de Geografia e Estatística IBGE) of 2010. The proportion of homicide by shooting deaths was calculated by the total of deaths from external causes, and the proportion of deaths according to the neighborhood over the total deaths at the site of assault by firearms.

Data were processed in Excel, then geocoded by geographic area according to neighborhoods using the cartographic database from the Secretariat of the Maceió City Planning (Secretaria do Planejamento do município de Maceió), Alagoas, and ArcView program 3.0 (license 756921101369). For statistical analysis, the database was formatted according to the software Statistical Package for Social Sciences - SPSS (21), serial No. 10101121162.

This study is part of the research named Spatial patterns of mortality by aggression and social inequalities in the city of Maceio, developed between the Universidade Federal de Alagoas and the Universidade de São Paulo (CNPq Project 150654/2012-0).

\section{RESULTS}

The Municipal Department of Health recorded 2,129 Maceió death certificates (DD) from external causes in 2012. Of these, 1,071 (50.3\%) were victims living in Maceió, with 805 (75.2\%) being by assault and 684 were shooting victims, which were intentional assaults or homicides classified in the categories X93 to X95 of ICD 10, and that represented $63.9 \%$ of deaths from external causes and $85.0 \%$ of deaths recorded by assault.

Among the 684 residents killed by shooting deaths, some exclusions were carried out: one had information of the same victim in two DD; and 49 with death occurrences recorded in other municipalities. Of the 634 assaults by firearm, it was found that four $(0.6 \%)$ were due to acci- dents, and four $(0.6 \%)$ were ignored. This study included 626 (98.7\%) homicides caused by firearms.

\section{Homicides CAUSED BY FIREARMS}

In 2012, the average number of homicides in Maceió/ $\mathrm{AL}$ was $52 /$ month. By analyzing homicides during the year, it appears that in the second half there was a decrease in the number of deaths from shootings. In the first half of 2012, there were 371 (59.3\%) deaths, and in the second half 255 $(40.7 \%)$ deaths. It appears that the killings varied during the year from 7.4 per 100 thousand inhabitants in January 2012 to 5.0 per 100 thousand inhabitants in December of that year, with a decline of $32.4 \%$ in this period.

The age of the victims ranged from less than one (1) to 82 years of age. According to Table 1 , men were the main victims of homicides in $93.6 \%$ of cases, with an average age of 27.4 years, median of 24.3 years and standard deviation of 11.3 years. Women accounted for $6.4 \%$ of cases, with an average age of 26.4 years, median of 24.9 years and standard deviation of 9.35 , with a range of 15 years to 53.2 years.

Regarding young adults aged $15-39$ years, the proportion was $84.4 \%$ of male deaths and $89.0 \%$ of female deaths. The total number of young people living in Maceió in the age group 15 to 29 years account for $68.8 \%$ of people who were killed by firearms (Table 1 ). The sex ratio of homicides in Maceió is 14.6 men for each woman.

Table 1 - Distribution of proportional mortality rates of homicides caused by firearms according to gender and age group (years) - Maceió, AL, Brazil, 2012.

\begin{tabular}{|c|c|c|c|c|c|c|}
\hline \multirow{3}{*}{$\begin{array}{l}\text { Age group } \\
\text { (years) }\end{array}$} & \multicolumn{4}{|c|}{ Gender } & \multirow{2}{*}{\multicolumn{2}{|c|}{ Total }} \\
\hline & \multicolumn{2}{|c|}{ Male } & \multicolumn{2}{|c|}{ Female } & & \\
\hline & $\mathbf{N}^{0}$ & $\%$ & $\mathrm{~N}^{\circ}$ & $\%$ & $\mathbf{N}^{o}$ & $\%$ \\
\hline$<1$ & 2 & 0.3 & 0 & 0.0 & 2 & 0.3 \\
\hline 05 to 09 & 1 & 0.2 & 0 & 0.0 & 1 & 0.2 \\
\hline 10 to 14 & 12 & 2.1 & 0 & 0.0 & 12 & 1.9 \\
\hline 15 to 19 & 140 & 23.9 & 10 & 25.0 & 150 & 24.0 \\
\hline 20 to 29 & 261 & 44.6 & 19 & 47.5 & 280 & 44.8 \\
\hline 30 to 39 & 93 & 15.9 & 7 & 17.5 & 100 & 16.0 \\
\hline 40 to 49 & 44 & 7.5 & 2 & 5.0 & 46 & 7.4 \\
\hline 50 to 59 & 22 & 3.8 & 2 & 5.0 & 24 & 3.8 \\
\hline 60 to 69 & 7 & 1.2 & 0 & 0.0 & 7 & 1.1 \\
\hline 70 to 79 & 1 & 0.2 & 0 & 0.0 & 1 & 0.2 \\
\hline$\geq 80$ & 2 & 0.3 & 0 & 0.0 & 2 & 0.3 \\
\hline Total & 585 & 93.6 & 40 & 6.4 & 625 & 100 \\
\hline
\end{tabular}

Mortality rates by homicides in Maceió were 65.2 per 100,000 inhabitants, with 130.6 per 100,000 men and 7.8 per 100,000 women. Figure 1 shows the mortality rates of homicides with firearms of residents in Maceió in 2012, according to gender and total. It appears that both genders have the same pattern of deaths in the age group between 15 and 29 years, meaning this is the group with the highest death rate per 100 thousand inhabitants. 


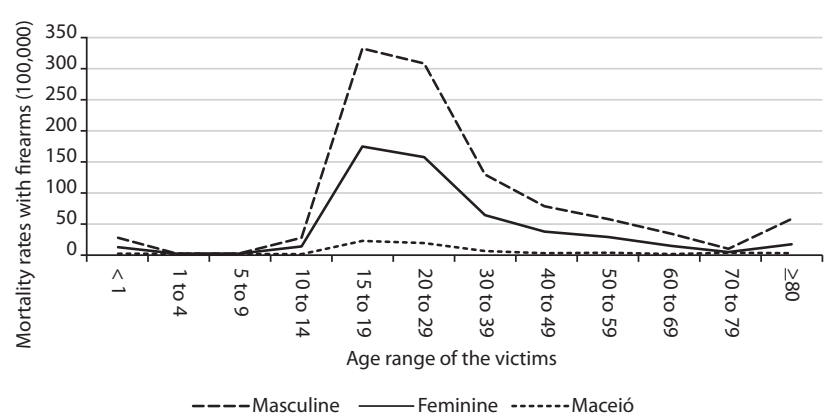

Figure 1 - Distribution of mortality rates per 100 thousand of homicides caused by firearms, according to gender and age group (years) - Maceió, AL, Brazil, 2012.

In relation to the marital status of victims of homicide caused by firearms, $8.3 \%$ were married, and $80.2 \%$ had no marriage bond. As for the day of the week, $54.2 \%$ of the cases occurred at the end of week, where Sunday was the day with the highest proportion of deaths at $20.8 \%$. It was observed that $68.6 \%$ of homicide deaths occurred in the evening (25.2\%) and at night (43.4\%).

Among the homicides according to the place of occurrence of death, the most common occurrence was in public areas $(74.1 \%)$, where it was found that $75.1 \%$ were male deaths and $60 \%$ female deaths. The second most common site for deaths were in hospitals (20.8\%). $4.2 \%$ of all deaths occurred at home (Table 2).

Homicide by firearms in Maceió had 455 (72.7\%) cases occurring on streets or roads and 444 (97.6\%) deaths happened on public roads. Among those that happened in the hospital, $75.4 \%$ of the assaults occurred in areas of commerce and service.

Among the neighborhoods where deaths occurred, Trapiche had the highest incidence (23.8\%). Of these, $96.2 \%$ occurred in hospital, as that is the location of the main public emergency hospital in the city.

DD's have a space to be filled with the address where the assault occurred when the death has not occurred in a health facility, meaning that it happened at the deceased's residence, public areas or elsewhere. Thus, 134 homicides were excluded for the analysis of the proportions of occur- rences of homicides by firearms, according to the neighborhoods of Maceió where the address of where death occurred was a hospital or health facility.

Maceió is divided into 50 neighborhoods. It is noteworthy that of all deaths where the assault happened on a public road or at a home, seven (14\%) neighborhoods that have $45.2 \%$ of the inhabitants of Maceió had $59.8 \%$ of the homicides caused by firearms in 2012. These districts were: Tabuleiro do Martins (12\%), Jacintinho (10.5\%), Benedito Bentes (8.9\%), Cidade Universitaria (8.9\%), Vergel do Lago (8.3\%), Clima Bom (6,2\%) and Trapiche da Barra (5\%). The proportion in other neighborhoods ranged from 0 to $3.7 \%$, and no homicides were registered in two districts (Chã de bebedouro and Ouro Preto).

The distribution of proportions of homicide occurrences caused by firearms according to the districts of Maceió are presented in Figure 2, with the values stratified by standard deviation values $(2.9 \%)$ in relation to average $2 \%$.

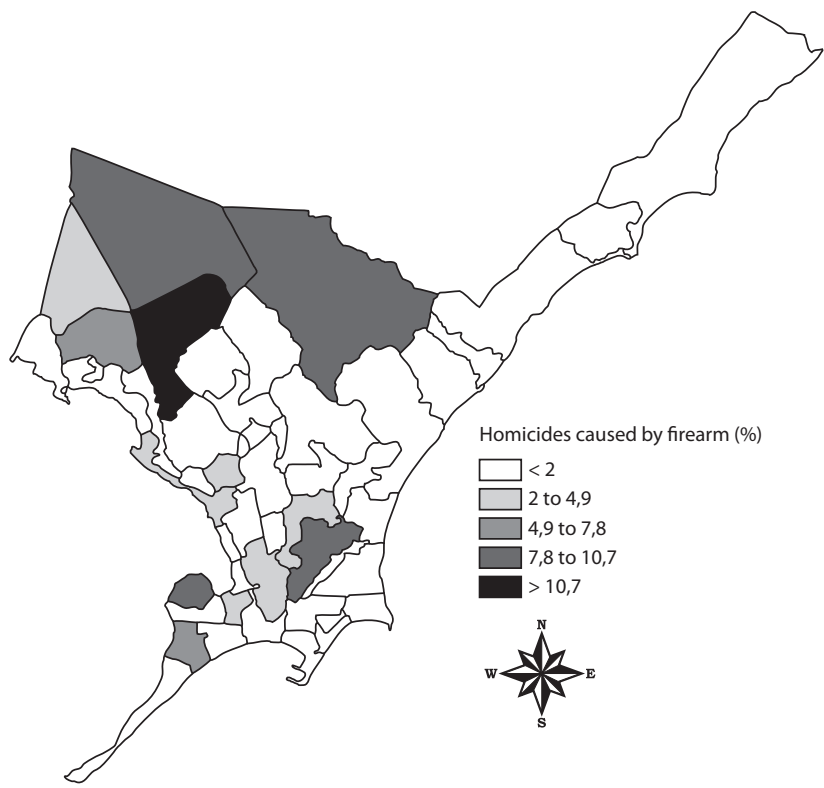

Figure 2 - Distribution Map of the proportion of deaths that occurred in places with firearm assaults - Located in the East - Atlantic Ocean - Maceió, AL, Brazil, 2012.

Table 2 - Distribution of place of occurrence of homicides caused by firearms according to the place of occurrence of assault and gender - Maceió, AL, Brazil, 2012.

\begin{tabular}{|c|c|c|c|c|c|c|c|c|c|c|c|c|}
\hline \multirow{3}{*}{$\begin{array}{l}\text { Place of occurrence of the } \\
\text { assault }\end{array}$} & \multicolumn{12}{|c|}{ Place of occurrence of death } \\
\hline & \multicolumn{2}{|c|}{ Hospital } & \multicolumn{2}{|c|}{ Other health facilities } & \multicolumn{2}{|c|}{ Public areas } & \multicolumn{2}{|c|}{ Household } & \multicolumn{2}{|c|}{ Others } & \multicolumn{2}{|c|}{ Total } \\
\hline & $\mathbf{N}^{\circ}$ & $\%$ & $N^{\circ}$ & $\%$ & $\mathrm{~N}^{\circ}$ & $\%$ & $\mathbf{N}^{0}$ & $\%$ & $\mathbf{N}^{\circ}$ & $\%$ & $\mathbf{N}^{\circ}$ & $\%$ \\
\hline Streets or Roads & 9 & 2.0 & 0 & 0.0 & 444 & 97.6 & 1 & 0.2 & 1 & 0.2 & 455 & 72.7 \\
\hline A. of comm. and serv. ${ }^{1}$ & 86 & 75.4 & 4 & 3.5 & 1 & 0.9 & 23 & 5.1 & 0 & 0.0 & 114 & 18.2 \\
\hline Schools and others ${ }^{2}$ & 0 & 0.0 & 0 & 0.0 & 1 & 100 & 0 & 0.0 & 0 & 0.0 & 1 & 0.2 \\
\hline Not specified & 35 & 62.5 & 0 & 0.0 & 18 & 32.1 & 2 & 0.4 & 1 & 0.2 & 56 & 8.9 \\
\hline \multicolumn{13}{|l|}{ Gender } \\
\hline Male & 118 & 20.1 & 4 & 0.7 & 440 & 75.1 & 22 & 3.8 & 2 & 0.3 & 586 & 100 \\
\hline Female & 12 & 30.0 & 0 & 0 & 24 & 60.0 & 4 & 10.0 & 0 & 0.0 & 40 & 100 \\
\hline Total & 130 & 20.8 & 4 & 0.6 & 464 & 74.1 & 26 & 4.2 & 2 & 0.3 & 626 & 100 \\
\hline
\end{tabular}

Source: Secretaria Municipal de Saúde de Maceió.

${ }^{1} \mathrm{~A}$. of comm. and serv.: Areas of commerce and service

${ }^{2}$ Schools and others: Schools, other institutions and areas of public administration. 


\section{DISCUSSION}

Nowadays, violence by firearms is a serious issue of public health and public safety, requiring effective actions by managers to combat it.

Epidemiological studies of mortality from homicide by shooting make it possible to know the extent of this violence, its prevalence and characteristics, supporting the public policies of prevention, promotion and public safety. The use of violence to resolve conflicts in contexts marked by broad social inequality, lack of opportunity and inefficiency of public institutions of security and justice has been reflected in recent years by the increase in violent deaths in Brazil ${ }^{(6)}$.

This study, conducted by the information contained in $\mathrm{DD}$, has some limitations such as insufficient data on education and occupation of victims recorded as unknown, as well as the non-assault registry for location when deaths occur in hospital.

The results show that homicides caused by firearms in Maceió in 2012 did not present heterogeneously in terms of its distribution between the sexes and age groups, as well as in terms of the circumstances of death and the places where the assaults occurred.

The severity and intensity of homicides by firearms among young men is visible. Homicide by firearms affects the society of the capital of Alagoas differently, since men are the main victims. Another disturbing aspect of these killings is the concentration in the population of adolescents and young adults, whose rates are higher than those found for the population as a whole. This result is also found in other studies in Brazil and worldwide ${ }^{(3,6,9,14)}$ in men between 15 to 39 years being the main victims, and they are also the main perpetrators of the deadly violence ${ }^{(15-16)}$. Death in the form of homicides resulting from firearm use affects young men, which shows how much they are exposed to violence.

The Map of Violence for 2013 on death caused by firearms in Brazil corroborates the findings of this study, also showing that young people are more vulnerable to be a fatal victim of firearms. The author reveals that in a three decade period (1980-2010), the growth of mortality among young people from firearms was even more intense when it is found that in the overall population, the numbers grew $346.5 \%$ over the 30 years, and, among young people, this growth was $414 \%{ }^{(4)}$.

Youth homicide grew more rapidly: in the population as a whole it was $502.8 \%$, but among young people, the increase was $591.5 \%$ (the source of information is in the reference $)^{(3)}$. The increase in violence among young people is due to the exclusion of education, as they are people who find little insert: they do not study, they cannot work and they have a lack of future perspective ${ }^{(3)}$.

The predominance of victims without marital bond presented in this study may be related to the age of homicide shooting victims, since most of the victims are young, which leads them to adventure and take more risks, becoming more vulnerable to external causes ${ }^{(17)}$.

Among homicides by firearms, it was found that deaths occur mainly on streets, meaning where the assault happened. This result calls attention to the fact of intention and violence, which does not allow the victim the chance of survival. A minor proportion of victims survive assault, and of this, $1 / 3$ of women who initially survived the shooting died in the hospital.

In hospital admissions of the Unified Health System (SUS) in Maceió in 2012, it was found that there were 210 admissions of firearm victims living in the city, and 189 (90\%) were male and 21 (10\%) females ${ }^{(11)}$.

As for assaults with firearms in which victims are rescued, one cannot help but say that the damage that they cause is significant and not just for the victims. Injuries, traumas and deaths caused by violence correspond to high emotional and social costs, and to public security devices. They cause economic losses due to days of absence from work, untold mental and emotional damage to the victims and their families, and the years of productivity or life lost ${ }^{(1)}$.

In a descriptive study at the Emergency Hospital of Goiânia-GO for only public service reference in emergencies and medium-sized emergencies, we found that the quality of life of victims of violence by firearms in general is compromised. Approximately $2 / 3$ of the victims of the study, which were for the most part young adults, developed symptoms suggestive of Post-Traumatic Stress Disorder related to interpersonal violence caused by firearms ${ }^{(18)}$.

The experience of violence can decrease the responsiveness of the victim to the world, with loss of interest in activities, depression, apathy and trigger family problems ${ }^{(1)}$. The lives of the victims, families and friends are affected by violence, and it is clear that this topic should be relevant to the public health prevention agenda ${ }^{(16)}$.

As for the health system, the consequences of violence, among others, are evident in the increase in emergency spending, assistance and rehabilitation, and much more expensive than most conventional medical procedures ${ }^{(11)}$.

From the above mentioned percentage, it appears that it's not just in large cities that violence is present. The peripheries of the cities are almost always stages of violence and death scenes; just remember the massacres and conflicts between gangs which are so common today, where we see a clear relationship between death and violence. This violence does not affect the population evenly, but more vulnerable population groups, which makes the problem more worrying because it is the population of young people who are the main victims of violence, jeopardizing the advances made in Brazilian life expectancy in recent times ${ }^{(9)}$.

One should not evaluate the incidence of crime by exclusively analyzing absolutism of numbers. Most of the time, the area of greatest population density is the one with a higher incidence of offenses ${ }^{(19)}$. However, in three districts in Maceió, which together account for $25 \%$ of the population, there were $1 / 3$ of homicides in 2012 , so it is necessary to investigate other factors that are involved in this violence.

Thus, the seven districts cited include a higher population density and the highest number of occurrences. An unfavorable physical and socioeconomic environment can often have a greater impact on individuals and promote the association of violence with poverty and social exclusion, with one of the outcomes being homicides by firearms ${ }^{(1)}$. 
As for the temporal distribution, the weekend was more representative in the incidence of homicide, with Sunday having the highest proportion of deaths. This finding is supported by another study, in which the weekends were periods when there was an increase in the number of cases, reaching $27.5 \%^{(17)}$, noting that this percentage is even lower than that recorded in Maceió. Also, $68.6 \%$ of homicide deaths occurred in the afternoon periods (25.2\%) and evening (43.4\%).

When faced with data from other realities, this information resembled research that aimed to trace the epidemiological profile of injury victims of firearm bullet (gunshot) attended to in the emergency room of a university hospital in 2007. It was found that 34 (34.7\%) occurrences took place during the night/early morning, followed in the afternoon with eight $(8.2 \%)$ and in the morning with five (5.1\%) $)^{(17)}$.

These data lead us to believe that the weekends and circulation in unusual times by individuals in public places of amusement with higher consumption of alcohol and other drugs can promote the involvement and/or exposure to situations of violence that lead to assault by firearms. This information is important to organize the provision of health services regarding the rescue of the victims, such as care in emergency facilities.

In the case of the distribution of homicides caused by firearms according to the neighborhood occurrence in $\mathrm{Ma}-$ ceió in 2012, it was found from the disaggregate data for neighborhoods that mortality from firearms can show fluctuations, revealing the existence of different focuses of violence in the city. It is important to check the distribution of the supply of state services and public safety, as the absence of these services contributes to the conduct of young people to crime and violence seen in neighborhoods.

Violence is a problem that strongly affects health because it causes death and decreases the quality of life, among other individual and social consequences, with new problems in health care, making the need clear for more specific, interdisciplinary, multidisciplinary, and intersectoral action, seeking an effective contribution to its discussion and prevention ${ }^{(20)}$.

Extrapolating the Cartesian approach in research on the epidemiological profile of homicides and building a reflec- tion on this phenomenon in the light of theoretical aspects, such as male dominance, power relations and social representations of violence is a major challenge for researchers and the scientific community ${ }^{(21)}$.

\section{CONCLUSION}

Although homicides are present in almost all districts of the capital of Alagoas, they are not distributed evenly in time and location. They occur mostly on weekends and at night. In respect of the area, the displayed map of violence shows heterogeneous areas for the occurrence of assaults by firearms in the city. There are therefore areas in the city where the population is more vulnerable to violence by shooting, featuring the existing urban inequality in its distribution.

The reduction of homicides caused by firearms in the second half of 2012 in Maceió should be investigated in previous years and later in order to see whether this is a temporal pattern for the municipality or if it is a behavior that may be associated with other aspects inherent to the process, such as the action that year by the National Army (Força Nacional).

The study on the profile of victims of homicides caused by firearms using the DD as a data source provides enough information to characterize the victims and the magnitude of the occurrence of homicides, how the violence is distributed, and how it affects the population. Thus, one of the contributions of this research is to give visibility to homicides by firearms and identified areas of its high prevalence, providing important information for the planning of public policies for public health and safety.

Violence is a socio-historical phenomenon which directly affects the health of victims, family and community. Thus, the health sector should be concerned about the victims, so it can act in the care and promotion of health and quality of life. To reduce homicides caused by firearms and their impact on health is important in order to overcome repression and to adopt multifocal and intersectoral measures to ensure the involvement of public and private power, social groups, families and citizens, meaning that it needs the inclusion and participation of the whole of society.

\section{RESUMO}

Objetivo: Descrever o perfil das vítimas e das agressões por projétil de arma de fogo, cujo desfecho foi o óbito. Método: Estudo ecológico, realizado no município de Maceió/AL, em 2012. Os dados foram coletados junto às Declarações de Óbitos. As variáveis estudadas foram: circunstância do óbito, sexo, idade, estado civil, local, dia, hora, mês e proporção segundo o bairro de ocorrência. Resultados: A taxa de mortalidade por homicídios foi de 65,2 por 100 mil habitantes, sendo 130,6 por 100 mil homens e 7,8 por 100 mil mulheres. Do total de homicídios, 93,6\% das vítimas eram homens. A faixa etária de 15 a 29 anos foi a mais atingida, com 68,8\%. Em 97,6\% dos casos o óbito ocorreu no local da agressão, 74,1\% em via pública. Em relação ao dia, 54,2\% dos casos ocorreram entre sexta-feira e domingo. Sete bairros concentraram 59,7\% dos homicídios. Conclusão: O mapa da violência apresentado mostra regiões heterogêneas para a ocorrência das agressões por arma de fogo, caracterizando a desigualdade urbana existente na distribuição da violência.

\section{DESCRITORES}

Violência; Homicídio; Coeficiente de Mortalidade; Iniquidade Social; Estudos Ecológicos.

\section{RESUMEN}

Objetivo: Describir el perfil de las víctimas y las agresiones por proyectil de arma de fuego, cuyo resultado fue el fallecimiento. Método: Estudio ecológico, llevado a cabo en el municipio de Maceió/AL en 2012. Los datos fueron recogidos de los Certificados de Defunción. 
Las variables estudiadas fueron: circunstancia del fallecimiento, sexo, edad, estado civil, sitio, día, hora, mes y proporción según el barrio de ocurrencia. Resultados: El índice de mortalidad por homicidios fue del 65,2 por 100 mil vecinos, siendo el 130,6 por 100 mil varones y el 7,8 por 100 mil mujeres. Del total de homicidios, el 93,6\% de las víctimas eran hombres. El rango de edad de 15 a 29 años fue el más involucrado, con el 68,8\%. En el 97,6\% de los casos, la defunción sucedió en el sitio de la agresión, el 74,1\% en la calle. Con respecto al día, el 54,2\% de los casos sucedieron entre los viernes y domingos. Siete vecindades concentraron el 59,7\% de los homicidios. Conclusión: El mapa de la violencia presentado muestra zonas heterogéneas en la ocurrencia de las agresiones por arma de fuego, caracterizando la desigualdad urbana existente en la distribución de la violencia.

\section{DESCRIPTORES}

Violencia; Homicidio; Tasa de Mortalidad; Inequidad Social; Estudios Ecológicos.

\section{REFERENCES}

1. Minayo MC. Violência: um problema de saúde pública no Brasil. In: Brasil. Ministério da Saúde; Secretaria de Vigilância em Saúde. Impacto da violência na saúde dos brasileiros. Brasília: Ministério da Saúde; 2005. p. 10-35.

2. Duarte EC, Garcia LP, Freitas LRS, Mansano NH, Monteiro RA, Ramalho WM. Associação ecológica entre características dos municípios e o risco de homicídios em homens adultos de 20-39 anos de idade no Brasil, 1999-2010. Ciênc Saúde Coletiva. 2012;17(9):2259-68.

3. Waiselfisz JJ. Mapa da violência 2013: mortes matadas por armas de fogo [Internet]. Rio de Janeiro: CEBELA/FLACSO; 2013 [citado 2014 out. 02]. Disponível em: http://www.mapadaviolencia.org.br/pdf2013/MapaViolencia2013_armas.pdf

4. Peres MFT, Vicentin D, Nery MB, Lima RS, Souza ER, Cerda M, et al. Queda dos homicídios em São Paulo: uma análise descritiva. Rev Panam Salud Publica [Internet]. 2011 [citado 2015 mar. 25];29(1):17-26, Disponível em http://www.ncbi.nlm.nih.gov/pmc/articles/ PMC3325790/

5. Brasil. Confederação Nacional dos Municípios. Estudos Técnicos. Homicídios por armas de fogo no Brasil: taxas e números de vítimas antes e depois da Lei do Desarmamento [Internet]. Brasília; 2010 [citado 2013 jul. 30]. Disponível em: http://portal.cnm.org.br/sites/9000/9070/ Estudos/SegurancaPublica/EstudoArmasdeFogo-CNM.pdf

6. Peres MFT, Santos PC. Mortalidade por homicídios no Brasil na década de 90: o papel das armas de fogo. Rev Saúde Pública [Internet]. 2005 [citado 2014 out. 02];39(1): 58-66. Disponível em: http://www.scielo.br/pdf/rsp/v39n1/08.pdf

7. Costa FAMM, Trindade RFC, Santos CB. Deaths from homicides: a historical series. Rev Latino Am Enfermagem [Internet]. 2014 [cited 2015 Apr 04];22(6):1017-25. Available from: http://www.scielo.br/pdf/rlae/v22n6/0104-1169-rlae-22-06-01017.pdf

8. Guedes RN, Fonseca RMGS, Egry EY. The evaluative limits and possibilities in the Family Health Strategy for gender-based violence. Rev Esc Enferm USP [Internet]. 2013 [cited 2014 Jan 28];47(2):304-11. Available from: http://www.scielo.br/pdf/reeusp/v47n2/en_05.pdf

9. Waiselfisz JJ. Mapa da violência 2011: os jovens no Brasil [Internet]. São Paulo: Instituto Sangari; 2011 [citado 2014 out. 02]. Disponível em: http://www.sangari.com/mapadaviolencia/pdf2011/MapaViolencia2011.pdf

10. Brasil. Ministério da Justiça. Programa Brasil Mais Seguro [Internet]. Brasília; 2012. [citado 2013 jul. 25]. Disponível em: http://www. justica.gov.br/sua-seguranca/seguranca-publica/programas-1/brasil-mais-seguro

11. Brasil. Ministério da Saúde. DATASUS. Informações de Saúde [Internet]. Brasília; 2012 [citado 2013 jul. 25 ]. Disponível em: http://www2. datasus.gov.br/DATASUS/index.php?area=02

12. Programa das Nações Unidas para o Desenvolvimento (PNUD). Relatório do Desenvolvimento Humano 2014. Sustentar o Progresso Humano: reduzir as vulnerabilidades e reforçar a resiliência. Lisboa: Camões Instituto da Cooperação e da Língua; 2014.

13. Almeida Filho L, Barreto ML. Desenho de pesquisa em epidemiologia. In: Almeida Filho N, Barreto ML, organizadores. Epidemiologia e saúde: fundamentos, métodos e aplicações. Rio de Janeiro: Guanabara; 2012. p. 165-85.

14. Souza TO, Souza ER, Pinto LW. Evolução da mortalidade por homicídio no Estado da Bahia, no período de 1996 a 2010 . Ciênc Saúde Coletiva [Internet]. 2013 [citado 2014 ago. 26];19(6):1889-900 [citado 2014 ago. 26]. Disponível em: http://www.scielo.br/pdf/csc/ v19n6/1413-8123-csc-19-06-01889.pdf

15. Belon AP, Barros MBA, Marín-León L. Mortality among adults: gender and socioeconomic differences in a Brazilian city. BMC Public Health [Internet]. 2012 [cited 2014 Oct 02];12:39. Available from: http://www.ncbi.nlm.nih.gov/pmc/articles/PMC3328284/

16. Velis E, Shaw G, Whiteman AS. Victim's profile analysis reveals homicide affinity for minorities and the youth. J Inj Violence Res [Internet]. 2010 [cited 2014 Aug 26];2(2):67-74. Available from: http://www.ncbi.nlm.nih.gov/pmc/articles/PMC3134912/

17. Zandomenighi RC, Martins EAP, Mouro DL. Ferimento por projétil de arma de fogo: um problema de saúde pública. Rev Min Enferm. $2011 ; 15(3): 412-20$.

18. Mello-Silva ACC, Brasil VV, Minamisava R, Oliveira LMAC, Cordeiro JABL, Barbosa MA. Care and outcomes of relaxation room assistance at a public maternity hospital, Rio de Janeiro, Brazil. Texto Contexto Enferm [Internet]. 2012 [cited 2014 July 25];21(3):558-65. Available from: http://www.scielo.br/pdf/tce/v21n3/en_v21n3a11.pdf

19. Santos LCC. Violência e criminalidade: um estudo dos dados existentes em Teresina - PI [Internet]. 2012 [citado 2013 jul. 25]. Disponível em: http://www.egov.ufsc.br/portal/conteudo/viol\%C3\%AAncia-e-criminalidade-um-estudo-dos-dados-existentes-em-teresina-pi

20. Minayo MC. Violência e saúde. Rio de Janeiro: FIOCRUZ; 2006.

21. Souza TO, Pinto LW, Souza ER. Spatial study of homicide rates in the state of Bahia, Brazil, 1996-2010. Rev Saúde Pública [Internet]. 2014 [cited 2014 Aug 27];48(3):468-77. Available from: http://www.scielo.br/pdf/rsp/v48n3/0034-8910-rsp-48-3-0468.pdf 